\title{
CAROL I OF ROMANIA - A LORD/KING WHO \\ REIGNED AND RULED. THE FORMULA OF \\ THE DUALIST PARLIAMENTARY REGIME
}

TRANSPLANTED IN 1866

DOI: 10.24193 /SUBBiur.64(2019).4.5

Published Online: 2019-12-31

\section{Răzvan-Cosmin Roghină*}

\begin{abstract}
In this paper, we intend to clarify the theoretical practices supposed by the political regime transplanted by the Romanian political elite in the constitutional moment of 1866, from the Belgian Constitution of 1831. From the perspective of such an approach, we shall observe that the fundamental law of 1866 did not design a Domn (Lord)/King placed under the dictum 'the monarch reigns, but he does not rule', but an active head of state, constitutionally endowed with strong levers of power. Considering the Constituent's desire to give a reply to the authoritarian regime of A. I. Cuza, the recognized constitutional powers of the head of state, on the one hand, and the further developed political status of Carol I within the political and constitutional praxis, on the other hand, emphasizes the weaknesses and incapacities of the Romanian political class regarding the dimension of the head of state constitutional institution. We shall emphasize the role and powers of the Lord (Domn) in the formula of the dualist parliamentary regime, which was not fully understood by the Constituent and by the political class that afterwards exercised the fundamental law. A dualist parliamentary regime formula inevitably involves a head of state that reigns and rules. The path towards a monist parliamentary regime, which was much more compatible with the Constituent desires (as aversions and
\end{abstract}

* Assistant Professor, ‘Lucian Blaga’ University of Sibiu, Faculty of Law, razvan.roghina@ulbsibiu.ro 
aspirations), should have been provoked, in practice, by the representatives of the People. The dualist parliamentary regime - as an archetype of the political thinking of that era - was, in part, customary. The later character implies experience, knowledge, which the Romanian society, through its legal and political actors, did not have.

Keywords: Romania, constitutional transplant, 1866, Romanian Constitution of 1866; Belgian Constitution of 1831; dualist parliamentary regime; head of state authoritarianism in Romania.

\section{Introductive Considerations}

The first Constitution of Romania, in the modern sense of the concept, was adopted by a Constituent Assembly in $1866^{1}$. Promulgated on the day of Carol I oath (June 30 / July 12, 1866), the Constitution entered into force on 1/13 July 1866. Interestingly, the lord (Domn) Carol I took the oath on a Constitution that was not sanctioned by the People and was not in force. It was obvious for the Romanian political elite that the procedure for finalizing the adoption of the fundamental law had to be different. Through the artifice of representation, the Parliament, on behalf of the People, concluded a contract / pact with the monarch. The latter had to accept to reign under a constitution constructed, at least partial, outside the logic of the traditional monarchical absolute power. As such, the fundamental law was completed with the logic of national parliamentary representation, in the name of the People. The first modern constitution of the Romanians was constructed and understood as a 'pact', similar in the procedure of adoption with the French Charter of 1830.

1 The Romanian Constituion of 1866 is avalilable for reading at http://www.cdep.ro/pls/legis/legis _ pck.htp act text?idt=37755 (accesed on 05.11.2019). 
The Romanian fait accompli policy did not end when the Constitution entered into force. The political elite, together with the foreign lord, had to continue the Western recognition mission with a further scope of provoking an oriental (forced) tolerance or reconnaissance regarding the new international status of the young Romanian state. As such, the policy of maintaining good diplomatic relations with the Ottoman Gate was just beginning, in the sense of 'forcing' an official recognition of Carol I as the Prince (ruler) of Romania - organized politically as a free national and unitary state.

The foreign prince brought on the throne of the Romanian Principalities and the massive constitutional transplant carried out ${ }^{2}$ helped Romania to establish an international political identity3. The 'international envelope' of the transplant gradually reached its purpose. The 'national coating' was to be tested. The mirage of a parliamentary regime (in a liberal constitutional general scaffolding) was thought, by the political elite of that time, to be the main key for a European international acceptance and the best way to satisfy the internal desire to break from an authoritarian political past, i.e. the regime of A. I. Cuza (1859-1864-1866).

Therefore, having in mind these short historical contextualized prolegomena, we shall first find out the reasons for transplanting a (dualist) parliamentary regime in $\mathbf{1 8 6 6}$ - from where and why (in Section 2). In order to later identify the formula of the dualist parliamentary regime within the Romanian Constitution of 1866 (part of Section 4), we will, shortly, emphasize

${ }^{2}$ See R. C. RoghINĂ, Logica şi efectele transplantului constituional din 1866, Universul Juridic, Bucharest, 2016, pp. 161 et. seq.; M. GuȚAN, Transplant constituțional și constituționalism în România modernă 1802-1866, Hamangiu, Bucharest, 2013, pp. 354 et. seq..

3 Ibidem, passim. 
the main features of the pre-mentioned political regime, as a political logic archetype of that era (in Section 3). Afterwards, in Section 4, we shall demonstrate, by presenting the role and attributions of the Romanian Lord/King - as regulated by the fundamental law and linked to the ratios implied by the dualist parliamentary regime -, that the monarch was designed to reign and rule, despite the clear political aversions related to the head of state authoritarianism, envisaged by the constitutional moment of 1866 (a reply given to the cuzist regime). In the last part, we shall set a further link to the constitutional and political praxis of the period 1866-1914. Hence, in the present article, the 'static dimension' of the fundamental law will prevail, but in a contextualized manner, outside the box of traditional positivistic legal investigation.

\section{The Belgian Constitution of 1831 - cloned and transplanted in the Romanian state of 1866}

The Belgian Constitution of $1831^{4}$ expressed, according to its liberal identity, a representative government, the separation of powers in the state, the independence of justice, the rights and freedoms of the citizens and, last but not least, the supremacy of the fundamental law. It sought to limit the power of the monarch. This purpose can easily be deduced from the consecration of the monarch's irresponsibility and inviolability. Thus, the Belgian Constitution designed a political archetype for limiting the power of

4 The Belgian Constitution of 1831 is available for reading at: http://www.modern constitutions.de/nbu.php?page id=8294b7496ae06609fa222b156332446b\#Belgiumn (accessed on 03.09.2019). 
the head of state and paved a way for developing a modern executive. Unfortunately, the Belgian fundamental law did not clearly regulate the mechanisms for the balance of state powers, specific to the dualist parliamentary regime that it outlined and in the terms and logic of the up mentioned principles. The attributions of the powers and the relations between them were not set in a complete formula. This lack of information became a part of the Romanian constitutional transplant of 1866 . They were not noticed - because the Belgian Constitution was not fully understood by the Romanian Constituent and political class in general, and, in consequence, travelled together with the copied constitutional form.

2.1 What was intended in the internal state dimension, by adopting a certain fundamental law in 1866 ?

In 1866 it was sought to introduce a fundamental law that would be constituted in a reply given to the Cuzist authoritarian regime.

'Gentlemen, when the country overthrew the last government, it did not want to overthrow only the persons representing that government, but that state of things, the Constitution that was given to a Prince and under which that Prince did nothing but harm to the country. We must abolish that Constitution and put another in its place. (...) This Constitution must be, all the more, liberal as we want to replace a vicious past system and therefore should not be 
narrower than the other.' (Grigore Lahovari, in the Constituent Assembly meeting of June $18^{\text {th }}, 1866^{5}$ )

The Belgian constitution of 1831, perceived, at that time, as the most liberal in Europe, imposed itself, through the mentioned character, on the position of a constitutional model necessary to be followed. The Constituents, seeking to set up a strong parliamentary regime, couldn't have ignored, according to their thinking, the recognized performances of the Belgian fundamental legal act. In this respect, the main source of the constitutional transplant from 1866 enjoyed an apparent rational character. A counter model for the cuzist model was correctly chosen ${ }^{6}$. The constitution of Belgium depicted an inviolable and irresponsible head of state, who, unlike the Paris Convention (1858) and the Developing Statute of the Paris Convention (1864), was introduced, even if not under complete regulations (very important to remember) regarding the balance of powers in the state. Thus, the dictum 'the king reigns but he does not rule' remained to be challenged by adapting the transplanted constitutional regulations (an action which cannot be retained in the evaluation of the constitutional transplant, considering the internal political powers and role granted to the Romanian head of state) or to be provoked through political and constitutional practices (and, again, such

\footnotetext{
5 Our translation from Romanian: 'Domnilor, când țera a resturnat guvernul trecut nu a voit să restoarne numai personele care representau acel guvern, ci starea aceea de lucruri, ei Constituțiunea aceea care s-a dat pe mâna unui Principe și în temeiul căreia acel Principe nu făcea de cât reu țerei. Trebuie dar să desființăm acea Constituțiune și în locul ei să punem alta. (...) Această Constituțiune trebuie să fie cu atât mai mult liberală cu cât voim să o punem în locul unui sistem trecut vițios şi prin urmare nu trebuie să fie mai restrânsă de cât cealaltă.' See A. PENCOVICI, Desbaterile Adunarei constituante de la 1866 asupra constituției și legii electorale din România, Tipografia Statului, Curtea Șerban Vodă, Bucharest, 1883, p. 51 .

${ }^{6}$ R. C. RoghinĂ, 'Paramentrii raționali și iraționali ai transplantului constituțional de la 1866', in Studia Universitatis Babeş-Bolyai Iurisprudentia, nr. 1/2014, ppp. 92-96.
} 
actions remained only a mirage of the legal form aspirations and aversions of the constitutional moment of 18667 ). However, in order to obtain a constitutional formula of a non-governing head of state, the political actors should have understood the execution coordinates of the dualist parliamentary regime, that works only with a monarch integrated in the governing of the state. These coordinates should have been configured, gradually - in time - towards a monist parliamentary regime, in which the head of state has no possibilities of political control over the Government, the latter becoming by excellence a political emanation of the Parliament.

\subsection{Shortly, how it came to adopting dualist parliamentary regime formulas?}

The Romanian Constituent from 1866 transplanted the logic of the political regime contained by the Belgian fundamental legal act of 1831 . Romania, through the ratio means implied by a vast constitutional transplant, placed itself in the position of an unexperienced explorer in the logic of a dualist parliamentary regime, underpinned in the more general mirror of a parliamentary constitutional monarchy. Although in the Constituent debates the voice of the Romanian ad-hoc assemblies of 1857 was not absent, the problem of limiting the monarchial absolutism received an illogical final solution. The coherent constitutional debates from 1857, which understood and assumed the constitutional purpose of limiting the monarch's power through the logic of the principle of separation of powers in the state ${ }^{8}$, were, paradoxically, ignored. It is a paradox of political and legal thinking because

\footnotetext{
7 R. C. Roghină, Logica şi efectele transplantului... cit., ppp. 161-170.

${ }^{8}$ M. GUȚAN, op. cit., p. 301.
} 
the assumed mission of the Romanian political elite of that time was to develop a constitutional rupture from the authoritarian cuzist regime. In 1866, the necessity of reaching a compromise with prince Carol I, who was an essential element in the mechanism of the constitutional transplant external and internal finalities, placed the monist parliamentary monarchy outside the box of solutions and brought the dualist variant, even though it was not analyzed or debated in its political practices avatars. As a result, the desire to project a parliamentary regime with strong representative accents got thrown in a political game where the traditional monarchic power principles were pre-determinate and that is why rather a constitutional (auto)limited monarchy emerged 9 . The renunciation of the suspensive veto in favor of the absolute one, the confirmation of the Belgian formula of political responsibility of the Government both in front of the Parliament and of the Monarch, respectively the possibility of the latter to dissolve the legislature, set, in a clearly manner, a strong and active head of state.

As a normative construction, the Romanian Constitution of 1866 presented coherence (as a sum of information) but the logic within that coherence was not decoded by the Romanian political class, which did not really know what the transplanted political regime from the Belgian fundamental law meant. In this regard, the Constitutional debates ${ }^{10}$ and the political praxis that followed ${ }^{11}$ testify.

9 Ibidem, p. 394 et. seq..

${ }^{10}$ A. PENCOVICI, op. cit., passim.

${ }^{11}$ R. C. RoGHINĂ, op. cit., ppp. 260-314. 
3 The main features of the dualist parliamentary regime, as it was understood in the $19^{\text {th }}$ century

The lack of a clear constitutional prescription for the dualist parliamentary regime was not peculiar to the Belgian Constitution of 1831, but was a feature of the era. The dualist parliamentary constitutional monarchy ${ }^{12}$ was a rather a first consequence of the fact that the monarch's power started to be limited by a written fundamental law, which emphasized the principle of national sovereignty and, implicitly, the effects of representation. In other words, the regime in question was the result of the practice, of the evaluation of political events through the grid of principles and less the follow-up of concrete constitutional prescriptions ${ }^{13}$.

The European constitutional practice of the nineteenth century highlighted certain requirements for a living transposition of the complex mechanisms of the dualist parliamentary constitutional monarchy. The dualist parliamentary regime implied a balance of power between the parliament and the monarch. This scheme of balance, being sometimes based even on hazard ${ }^{14}$, could easily be lost. The lack of a coherent political ideology archetypes and, as a consequence, the absence of clear constitutional prescriptions caused the institutional-constitutional transformations specific to the dualist parliamentary regime to be challenged through political capacities and constitutional loyalty, not just assumed in legal text. This formula of unfolding or developing political life was normal, as a transitional

\footnotetext{
12 See M. GuȚAn, op. cit., ppp. 369-379.

13 P. PACTET, Institutions politiques. Droit constitutionnel, Masson, Paris, 1986, p. 143. 14 Ibidem.
} 
practice from the (self)limited monarchy to the parliamentary regime ${ }^{15}$ was being put into practice, so it had to be managed through new experiences.

The representative assemblies, in the light of their increased legitimacy, began to compete with the monarch's power. In this direction, the ministers were removed from the status of mere personal agents of the monarch and were introduced into the political scheme of a government emanating from the forum with the highest degree of representativeness - the parliament. It was due to the principle of national sovereignty and due to the principle of representativeness. At the same time, staging the inviolability and irresponsibility of the monarch, through the political and legal accountability of the ministers, the legislative started to limit the executive power. The signature of the head of state received the mere political ratio of authenticating the decisions taken by a political responsible prime minister or by competent ministers in certain fields of activity ${ }^{16}$. The ministerial counter-signature removed the monarch from political and legal responsibility. But the logic of the dualist parliamentary constitutional monarchy does not end at this point, but on the contrary, it acquires its specificity by the fact that the executive power limits the legislative power. In this sense a dual political responsibility of the ministerial cabinet was outlined. In concreto, it was politically accountable to both the parliament and the monarch. From within this circumstance or context a delicate balance between the legislative and the executive developed.

15 C. CREWE, H. RuIz FABri, Droits constitutionnels européens, Presse Universitaire de France, Paris, 1995, p. 370.

${ }^{16}$ P. Pierre, op. cit., p. 146. 
In the dualist parliamentary regime, the government (ministerial cabinet/Council of ministers) had to enjoy both the confidence of the parliamentary majority and that of the monarch. The two-way responsibility of the ministers merged in the idea of limiting the executive, that was still identified with the monarch. The ministerial cabinet was rethought as a political infra-forum of mediation between the parliament and the monarch ${ }^{17}$. Therefore, it was important to ensure an institutional formula that would have allowed the legislature to effectively limit the power of the monarch. The appointment of ministers from the parliamentary majority was a requirement meant to weigh the monarch's right to appoint ministers. The dual responsibility of the government was programed to lead to a synthesis between the political views of the parliament and of the monarch ${ }^{18}$. As such, in the dualist parliamentary constitutional monarchy, the ministerial cabinet was the key for the stability of political life ${ }^{19}$, but also the reason for political instability. The Cabinet had to support and maintain the confidence of both poles of power. If it lost the monarch's confidence, had to resign. Interestingly, in the situation where the government no longer enjoyed the confidence of the parliament, the former was not obliged to submit a letter of resignation, although it was the political emanation of the latter ${ }^{20}$. A government couldn't have remained in power based only on the political support of the

\footnotetext{
17 C. CREWE, H. RUIZ FABRI, op. cit., p. 369.

18 Ibidem.

19 R. CAPITANT, 'Regimes parlementaires', in Mélanges Carré de Malberg, Paris: Sirey, 1933, p. 42.

${ }^{20}$ On the basis of parliamentary principles, the monarch would have had the obligation to form a cabinet from the parliamentary majority. See, A. EsMEIN, Éléments de droit constitutionnel français et comparé, Librairie Recueil Sirey, Paris, 1921, p. 142 et. seq.. https://archive.org/details/lmentsdedroi01esmeuoft (accessed on 02.10.2019).
}

\section{9}


parliament ${ }^{21}$, but could have remained in position based on the monarch's confidence. Of course, such a scenario was possible only by assuming the risk for serious political crisis. Therefore, another feature of the dualist parliamentary regime was the monarch's prerogative to dissolve the parliament. It is worth mentioning that in the parliamentarism logic the leverage of dissolving the parliament - a personal instrument of the monarch ${ }^{22}$ - was meant to unlock a governmental crisis and not to increase the power of the executive. The monarch had to resort to the dissolution of the parliament only when his political vision could no longer politically coexist with that of the legislature through the ministerial cabinet (it was also a way to limit the legislative power). In practice, this prerogative, although it was specific to parliamentarism, allowed the monarch to exert power through the ministerial cabinet, which again indicates that the dualist parliamentary monarchy was nothing more than a period of transition to the monist parliamentary regime, based not on customs, but on express constitutional rules. Its dualistic variant limited the power of the monarch to only a certain degree. This explains some remnants of the (auto)limited monarchy ${ }^{23}$.

The exercise of the constitutional leverage of the dissolution of the parliament brought the people in to the position of a political arbiter. The later was set to rule either in favor of the parliamentary majority politics, or in favor of that of the monarch ${ }^{24}$.

\footnotetext{
${ }^{21}$ M. GUȚAN, op. cit., p. 376.

22 R. CAPITANT, op. cit., p. 44.

23 M. GuȚAn, op. cit., pp. 374 et. seq.

${ }^{24}$ R. CAPITANT, op. cit., p. 44.
} 
Therefore, the dualist parliamentary regime emphasized a balance between legislative and executive. The balance between the parliament and the monarch (he was still identified with the executive power) was ensured by certain interdependent constitutional weights and counterweights. The legislature limited the power of the executive through its rights stemming from the government's political responsibility - the withdrawal of the political trust/ motion of censure -, and the monarch limited the legislative power by exercising the prerogative of dissolving the parliament. The aim was to create an autonomous government, capable of channeling a responsible general policy, mediated by its two-way responsibility. It was essential, in order to avoid the subordination of one power by another, that the control levers be reciprocal. Ideally, the monarch should have had a relative veto. Its absolute variant, specific to the (self)limited monarchy, was just too strong, caring a great risk of overturning the balance of power assumed by the dualist parliamentary regime, especially if the parliamentary majority was not composed by individuals with a clear and solid political ideology and capable of objectifying their political role in the complex equation of limiting the power of the monarch.

In the dualist parliamentary regime, the legislative power was exercised by both the parliament and the monarch. An absolute and unconditional right of veto was enough to subordinate the activity of the parliament to the exclusive will of the monarch, although, theoretically, he had the obligation not to use his co-sovereignty against those who represented the sovereignty of the people, i.e. the political power of origin.

The institutional scaffolding of the dualist parliamentary monarchy implied the acceptance of a complex balance of power. Any deviation from its (largely customary) rules could generate broad political crises and, finally, 
overturn the qualification of the political regime as a parliamentarian. It would not be an exaggeration to say that dualist parliamentarism was limited, on the one hand, to the will of the monarch and, on the other, to the ability of the people/nation's representatives to block the 'skids' of the former.

\section{Inside the Romanian Constitution of 1866. The Monarch - chief of the executive and co-legislator. The lord (Domn)/king doesn't rule?}

The Romanian Constitution of 1866 eliminated the elective-hereditary reign ${ }^{25}$, one of the defining elements of the medieval Romanian constitutionalism. The modern fundamental law consecrated a hereditary monarchy, excluding any possibility of returning to the old, domestic throne succession system. Article $87^{26}$ was clear in this regard.

Being a pact-constitution, concluded between the monarch and the People represented by the parliament, similar to the logic of the Orleanist pact of 1830, the monarch's power was not fully reflected in that of the People, but rather was combined or balanced with it, through the prism of the equality derived from the nature of the constitutional contract/pact. It is true that

\footnotetext{
25 For more information, see M. GuȚAN, Istoria dreptului românesc, 3rd edition, Hamangiu, Bucharest, 2017, ppp. 64-65.

26 Article 87: 'The constitutional powers of the lord are hereditary, within the direct and legitimate descent line of his Majesty Prince Carol I of Hohenzollern-Sigmaringen, from man to man through the order of primogeniture and with the perpetual exclusion of women and His descendants'. Our translation from Romanian: 'Puterile constituționale ale domnului sunt ereditare, în linie coborâtoare directă și legitimă a Măriei Sale principelui Carol I de Hohenzollern-Sigmaringen, din bărbat în bărbat prin ordinul de primogenitură și cu excluderea perpetuă a femeilor și a coborâtorilor ei.'.
} 
article $31^{27}$ (inspired by art. 25 of the Belgian Constitution of 1831) clarified the source of the sovereignty by expressing the principle of national sovereignty, but this did not lead to the elimination of certain specific elements of the (auto)limited monarchy.

The dualistic character of the transplanted parliamentary regime made the logic of the distribution of powers in the state to meet and absorb some political power elements recoverable in the theory of sovereignty under divine law. Compared to the constitutionalism of the 19th century, the combination of the parliamentary regime with the features of the (self)limited monarchy is explicable. The monarch was gradually removed from the landscape of effective governance. As it was already pointed out, the dualist parliamentary regime marked a stage of transition towards the full sovereignty of the People, represented by the parliament. Monist parliamentarism, as a complete expression of the principle of representation, appeared on the political scene of the European continent near the end of the 19th century, when the ministerial cabinet became the first holder of the executive power, politically responsible only in front of the parliament ${ }^{28}$. From this point of view, the conclusions of the ad-hoc Assemblies of 1857 , promoting a coherent theory of a monist parliamentary regime, gain a special significance for the Romanian constitutionalism, or even for the European constitutionalism ${ }^{29}$. In the same time, it can be stated that the constitutional

\footnotetext{
27 Article 31: 'All the powers of the State emanate from the nation which can only be exercised by delegation and following the principles and rules laid down in this Constitution'. Our translation from Romanian: 'Toate puterile Statului emană de la națiune care nu le poate exercita decât numai prin delegațiune și după principiile şi regulile aşezate în Constituțiunea de față. '.

${ }^{28}$ M. Morabito, Histoire constitutionnelle de la France (1789-1958), 9 édition, Montchrestien, Paris, 2006, p.305.

${ }^{29}$ M. GuȚAn, Transplant constituțional şi constituționalism... op cit., p. 309.
} 
moment of 1866 reveals a regression of political and constitutional thinking compared with the constitutional ideas of the year 1857. In 1866, constitutional forms were taken from a foreign societal background, and in 1857 ideas were evaluated and internal created. The accumulated difference should not surprise, taking into account the mitigating circumstances of the Constituent Assembly (external political pressures and risks regarding the survival of the young national and unitary Romanian state), on the one hand, and having in mind the fact that in the mid-nineteenth century it was difficult to attempt to fully remove the monarch from the act of governance, on the other hand.

As such, article $31^{30}$, article $32^{31}$ (inspired by articles 26 and 27 of the Belgian Constitution of 1831), article $33^{32}$ (inspired by article 27 of the Belgian Constitution of 1831) and article $35^{33}$ (inspired by article 29 of the Belgian Constitution of 1831), projected the active role that the monarch still held in the respective era.

Therefore, the monarch was involved in the equation of political decisions. The above articles did not differentiate the constitutional monarch

30 Supra footnote 27.

${ }^{31}$ Article 32: 'The legislative power is exercised collectively by the Lord and the national representation (...) No law can be subjected to the Lords sanction until after it has been discussed and freely voted by the majority of both chambers'. Our translation from Romanian: 'Puterea legislativă se exercită colectiv de către Domn și reprezentațiunea națională (...) Nici o lege nu poate fi supusă sancțiunii Domnului decât după ce se va fi discutat și votat liber de majoritatea ambelor adunări.'.

${ }^{2}$ Article 33: 'The legislative initiative is given to each of the three branches of the legislative power.' Our translation from Romanian: 'Inițiativa legislativă este dată fiecăreia dintre cele trei ramuri ale puterii legislative.'.

33 Article 35: 'The executive power is entrusted to the Lord, who exercises it on a regular basis through the constitution (...)'. Our translation from Romanian: 'Puterea executivă este încredințată Domnului, care o exercita în modul regulat prin constituțiune (...)'. 
from the head of state under the Paris Convention (1858) or under the Developing Statute (1864), but, on the contrary, likened them. The rupture from the past constitutional laws was enhanced by regulating the principle of inviolability and, as an effect, the monarch's irresponsibility. As such, article 35 of the Romanian Constitution from 1866 was, theoretically, set to be interpreted in the spirit of monarchial inviolability and irresponsibility, the governmental and administrative activity falling within the political and legal responsibility of the ministers, based on the legal and political effects of the countersigning institution. In other words, it was penciled, by interpretation, an open door, but guarded by 'internal political capacities', for the dictum the king reigns, but does not rule. This idea was quite difficult to put into practice at that time, by unexperienced political actors. Furthermore, it should not be overlooked that, although they are essential elements, the inviolability and irresponsibility of the monarch, with all its effects on the institution of Government and on the ministerial responsibility, does not guarantee the existence of a parliamentary regime, especially if it must be completed through interpretation. As the Belgian fundamental law did not fully clarify the monarch's role, the Romanian Constitution acquired, through legal transplantation, the same deficiency. In such a hypothesis of unknown avatars of state power, the specific elements of the (auto)limited monarchy could reaffirm and significantly diminish, if not even cancel, the parliamentary features of the political regime. Although, for example, article 35 of the Romanian Constitution stated that the Lord had no powers other than those given to him by the Constitution, it did not mean that the desired and regulated parliamentary regime could not acquire stronger characters in the direction of a (auto)limited monarchy. Since the constitutional text was ambiguous, the limits indicated by article 35 were also unclear. The 
deficiencies could, theoretically, be covered by the existing constitutional customs or, if they were lacking, by the rules specific to the institutional and functional structure of the parliamentary regime. In such circumstances, the monarch's personality had a decisive impact. The way he understood to get involved in government determined the difference between assuming the customs specific to the parliamentary regime and settling customs with monarchic characters.

Focusing only on the duties listed by the Romanian Constitution, the monarch from 1866 had inferior prerogatives than those enjoyed by the lord from 1859 or 1864 . However, having an absolute veto right, based on article $93^{34}$, the power of the monarch couldn't and shouldn't have been ignored.

The balance of powers, designed in a dualist parliamentary regime with a suspensive monarchal veto, was fragile. This fragility was even more profound in a formula of weights and counterweights that included an absolute and unconditioned monarchal veto. In the Romanian fundamental law of 1866, the veto prerogative was not limited by ministerial counter-signature. The monarch's refusal to sanction a law was free of any legal forms (e.g., decree, message). A simple abstaining was enough ${ }^{35}$. This aspect carried a clear risk towards political power personalization. The Constituent Assembly, not fully aware of the risks involved, accepted the absolute veto formula at the pressures of Prince Carol.

'June 8/20, 1866. The prince assembles a large number of deputies to entice them to agree on the constitution. The Chamber does not

34 Article 93: 'The Lord ... sanctions and promulgates the laws. He can refuse his sanction'. Our translation from Romanian: 'Dommul... sancționează și promulgă legile. El poate refuza sancţiunea sa.'.

35 P. Negulescu, Curs de drept constituțional, Bucharest, 1927, p. 429. 
want to grant the ruler but a conditioned, suspensive veto, such as that held by the president of the United States of America, while the prince demands an unconditional and absolute veto.' ${ }^{36}$

It follows that the future ruler of Romania wanted to have a say in the Romanian politics and, as such, demanded an absolute and, perhaps even more important, unconditional veto (no ministerial countersignature needed). From this circumstance we deduce that the prince was ready to respect the significance of the ministers' signature. He was aware that they were not going to be his personal agents, that they were not obliged to countersign his refusal to sanction a law. By demanding - practically - the elimination of the counter-signature condition, the prerogative of the veto would have had no constitutional limits in its expression. The prince took this into account and sought this constitutional confirmation. His pressures, thus, increased. The Prince emphasized the importance of his arrival on the Romanian throne, in the international context and in the context of the urgency for a Romanian Constitution. By doing so, he deprived the constituents of some possibilities or choices.

'June $15 / 27,1866$. The prince invited a large number of deputies to him, in the Cotroceni garden, and pleads with them, in the context of

${ }^{36}$ Our translation from Romanian: 'Prințul adună la dânsul un număr mare de deputați ca să-i înduplece să se înțeleagă asupra constituției. Camera nu vrea să acorde domnitorului decât un veto condiționat, suspensiv, care îl are președintele Statelor Unite ale Americii, pe când prințul cere un veto necondiționat și absolut'. See ***, Memoriile Regelui Carol I, de un martor ocular, Vol. I, S. NEAGOE (ed.), Scripta, Bucharest, 1992, p. 75. 
the serious international situation, to finish their work sooner (the discussion on the constitution).' 37

It is noteworthy that the absolute and unconditional veto was regarded as a specific prerogative for the monarch's arbitrator role, along with his right to dissolve the parliament, which, unlike the first power attribute, was conditioned by article 92. Thus, if the parliament and the government were in an agreement on the policy to be followed, the head of state couldn't, theoretically, promote his political agenda, by applying the rules of the parliamentary regime:

'June 26 / July 8 1866. The Chamber discusses Article 63 of the constitution, on the Prince's veto. After a short debate, an absolute veto is admitted by which the head of state can refuse to sanction of laws. At first, in the first project, it was about recognizing the prince only the right to dissolve the Chamber, in case of divergence of opinions with him, but, if the new Chamber had joined the vote of the dissolved Chamber, then the prince would have had to renounce any opposition and approve the sanction.' 38

When the absolute veto was removed from the requirement of ministerial counter-signature, wide political effects became inevitable. Basically, the monarch could block an unwanted law even in the case when the parliament and the government were in consensus. This circumstance

37 Our translation from Romanian: 'Prințul invită un număr mare de deputați la dânsul, în grădina de la Cotroceni, și-i conjură, în fața situației grave internaționale, să-şi termine mai curând lucrarea (discuția asupra constituției).’'See ibidem.

38 Our translation from Romanian: 'Camera discută articolul 63 al constituției, asupra dreptului de veto al prințului. După o scurtă dezbatere, se admite veto absolut în puterea căruia șeful statului poate să refuze sancționarea legilor. La început, în cel dintâi proiect, era vorba de a nu recunoaște prințului decât dreptul de a dizolva camera, în caz de divergență de păreri cu dânsul, dar, dacă noua cameră s-ar fi alăturat la votul celei dizolvate, atunci prințul să fie dator a renunța la orice împotrivire și a încuviința sancțiunea.' See ibidem, p. 80. 
became much more pressing when the praxis and the emerged politicalconstitutional theory recognized the monarch's right to dismiss or dissolve the Chambers even in the absence of a conflict. It was sufficient for him to consider that the respective political bodies were no longer working in the interest of the voters ${ }^{39}$. On the basis of the parliamentary rules, the head of state could not promote his own policy to the detriment of the political agreement between the Chambers and the ministerial cabinet. He could, at most, block the entry into force of a law, by exercising the right of veto ${ }^{40}$. However, the Cabinet, being also responsible in front of the monarch, could not channel its activity only in the direction of maintaining parliamentary support. Losing the monarch's confidence meant a great risk of dismissal. But, as the new Cabinet had to embrace the confidence of the same parliamentary majority, which disregarded the monarch's policies, the dissolution of the parliament could be preferred, for extra-parliamentary, personal reasons. The constitution of 1866 transformed the head of state into a truly third chamber of legislative power ${ }^{41}$. As a result, the dualist parliamentary regime will prove to be a supreme test for the Romanian political class. The later did not have a political thought capable to functionally exercise the coordinates of the transplanted political regime ${ }^{42}$.

39 T. MAIORESCU, Discursuri parlamentare. Cu priviri asupra desvoltării politice a României sub domnia lui Carol I, Vol. V (1895-1899), « Minerva », Bucharest, 1915, p. 198.

$4^{0}$ T. DRĂGANU, Începuturile şi dezvoltarea regimului parlamentar în România, pană la 1916, Edit. Dacia, Cluj-Napoca, 1991, p. 276.

${ }^{41}$ Ibidem, p. 192.

42 R. C. RoghinĂ, Logica și efectele transplantului... cit., ppp. 261-277; pp. 356 et. seq..

\section{9}


The executive power, according to article $35^{43}$, was entrusted to the Lord. Unlike the previous regime, the head of state was to exercise this power only in the manner established by the Constitution, according to article $93^{44}$.

Article 93 defined the profile of the monarch from 1866. As we have seen, his absolute veto entailed the risk of putting the parliament under the executive power. Bringing into this equation his (apparently) freedom to name and revoke the ministers, the monarch's position became central in the distribution of state power. This is how the Constitution of Belgium from 1831 prescribed the power distribution and, as an effect of the massive and faithful

43 Supra footnote 33 .

44 The Lord appoints and dismisses His ministers. He sanctions and promulgates the laws. $\mathrm{He}$ can refuse His sanction. He has the right to amnesty in political matters. He has the right to forgive or reduce the penalties in criminal matters, apart from what is established in the cases of ministers. He cannot suspend the course of the prosecution or of the trial, nor intervene in any way in the administration of justice. He appoints or confirms in all public functions. $\mathrm{He}$ cannot create a new function without a special law. He makes the regulations necessary for the laws execution without being able to modify or suspend the laws and cannot exempt anyone from executing them. He is the head of the armed forces. He confers military ranks according to the law. He will confer the Romanian decoration according to a certain law. He has the right to release currency under a special law. He concludes with the foreign States the conventions necessary for trading, navigation and regarding other such matters; but in order for these acts to have binding authority, they must first be subject to the legislative power and approved by it. Our translation from Romanian: 'El sancționează şi promulgă legile. El poate refusa sancțiunea $S a$. El are dreptul de amnistie în materie politică. Are dreptul de a ierta sau micşora pedepsele în materie criminală, afară de ceea ce se statornicește în privirea miniştrilor. El nu poate suspenda cursul urmărirei sau al judecății, nici prin a interveni prin nici un mod în administrația justiției. El numește sau confirmă în toate toate funcţiunile publice. El nu poate crea o nouă funcțiune fără o lege specială. El face regulamentele necesare pentru executarea legilor fără să poată vreodată modifica sau suspenda legile și nu poate scuti pe nimeni de executarea lor. El este capul puterei armate. El conferă gradurile militare în conformitate cu legea. El va conferi decorațiunea română conform unei anume legi. El are dreptul de a bate monedă conform unei legi speciale. El încheie cu Statele străine convențiunile necesare pentru comerciu, navigațiune și alte asemenea; însă pentru că aceste acte să aibă autoritate îndatoritore, trebuie mai întâi supuse puterii legislative și aprobate de ea.'. 
transplant, so did the Constitution of Romania from 1866. The Belgian fundamental law was directly inspired by the French Charter of 1830, which in turn took ideas from the Charter of 1814 - a fundamental law which regulated a limited monarchy45. It is, thus, understood why the Belgian Constitution was unclear regarding the role of the monarch, basically on his ambiguous political limits of action. However, in promoting the idea of national sovereignty, it was clear that the idea of representativeness was emphasized, on the legitimacy enhancement of the parliament, hence the transformation of the (auto)limited monarchy into parliamentary constitutional monarchy of a dualist type.

Since the Government, based on its constitutional regulation, had no clear political identity, it was the logic of parliamentarism that imposed certain customs regarding the appointment and dismissal of ministers. Only on the basis of an interpretation made in the spirit of parliamentarism could have been stated that the ministers were not personal agents of the monarch. The Parliament benefited from constitutional mechanisms of political control over the executive, and the inviolability and irresponsibility of the monarch were enshrined - directly or indirectly - in the fundamental law. These constitutional circumstances overturn the idea of a royal cabinet.

There should have been a greater political responsibility of the government in front of the Parliament. The fundamental law of 1866 did not

\footnotetext{
45 B. Deseure, 'National Sovereignty in the Belgian Constitution of 1831. On the Meaning(s) of Article 25', in: MÜßIG U. (eds) Reconsidering Constitutional Formation I National Sovereignty. Studies in the History of Law and Justice, vol 6, Springer, Cham, 2016, pp. 100 et. Seq.; (article is available, open source, at: https://link.springer.com/chapter/10.1007/978-3-319-42405-7 2\#citeas (accesed on 15.10.2019); M. GUȚAN, op. cit., pp. 147-148.
} 
expressly oblige the Lord to appoint most of the ministers from within the parliamentary majority, as it results from article $93^{46}$ and article $99^{47}$.

The stated parliamentary requirement - the government had to be the emanation of the parliament - was detached from the way in which the attributions of the legislative power were related to those of the executive. Within the (auto)limited monarchy the Government was nothing but a projection of the monarch. In the dualist parliamentary regime, it was the emanation of the Parliament, even if the appointments were made by the head of state. In the formula of a two-way political accountability of the ministers, it was logical that the monarch could not ignore the political vision of the parliamentary majority and impose his own political vision in the color of the Government. In the light of the balance imagined by dualist parliamentarism, the monarch and the Parliament had to be, at least in the first phase, in a political consensus. This obligation of the monarch, arising from the nature of the transplanted political regime, was also highlighted by G. G. Meitani, in 1878 , in his study on the articles of the Constitution of $1866^{48}$, showing that the lord's right to appoint ministers was not discretionary; this is because article 92 imposed the imperative of eliminating the monarch's responsibility of any kind, which made his direct involvement in the act of government illogical.

\footnotetext{
46 See supra footnote 34 .

47 Article 99: 'If the ministers were not members of the Assemblies, they can take part in the debate of the laws without having the right to vote'. Our translation from Romanian: 'Dacă miniștrii nu ar fi membri ai Adunărilor, ei pot lua parte la desbaterea legilor fără a avea însă şi dreptul de a vota.'.

48 G. G. MeITAni, Studie constituţionale, Noua Tipografie a Laboratorilor Români, Bucharest, 1878, p. 29.
} 
Therefore, by article 100, it was enforced that in no case can the verbal or written order of the Lord defend a minister responsibility 49.

In addition, article $98^{50}$ translated, implicitly, the logic of the dual political responsibility of the government, in which the ministers were not agents placed in the monarch's interest.

Thus, the bidirectional political responsibility removed the Government out of the exclusive views of the monarch. The later had to be mediated with those of the parliament, hence the essential feature of the dualist parliamentary regime: the balance of state policy was ensured by the fact that the Government was accountable to both the monarch and the parliament. There was no need for a full embrace of the political course desired by the parliamentary majority, as it was not compulsory to faithfully respect the monarch's political intentions. So, not only did the monarch appear as an arbitrator between the parliament and the government, in the light of exercising the prerogative of dissolving the Chambers or dismissing ministers, but the government also had the mission of amortizing a possible political program conflict between the monarch and the parliament ${ }^{51}$. These issues were favoring not only the parliament, but also the monarch. Through collaboration, the monarch could be politically active (to a point, it was to be expected).

\footnotetext{
49 Article 100, our translation from Romanian: 'În nici un caz ordinul verbal sau în scris al domnului nu poate apăra pe un ministru de răspundere.'.

50 Article 98: 'No member of the ruling family can be a minister.' Our translation from Romanian: 'Nici un membru al familiei Domnitoare nu poate fi ministru.'

${ }^{51}$ R. CAPITANT, op. cit., p. 42.
} 
Of course, this political activism had to be evaluated through the political agenda of the parliamentary majority ${ }^{52}$. Otherwise, we would witness the replacement of the practices of dualist parliamentarism with practices that translate powerful absolutist reminiscences.

It was essential for the monarch, having the intention to follow the rules of the parliamentary 'chessboard', to compose the ministerial cabinet from a majority approved by the Assemblies. If the ministers did not have parliamentary support, they could be left out of the debates of the Chambers, with the exception of only one of them. However, it should be noted that if the political balance obtained by appointing the ministers from the majority of the two Chambers disappeared, in the sense that a conflict between the Parliament and the Government intervened, the monarch was not obliged to dismiss the latter. He could dissolve the Chamber or Chambers, if the Government agreed with his political vision. Consequently, in the situation of governmental instability, the transplanted parliamentary regime involved two solutions. One was specific to parliamentarism, and another for the (auto)limited monarchy. The parliamentary solution was to dismiss the Government after a censure motion was adopted. The monarchical resolution was the one in which the Parliament (in whole or in part) was dissolved. Therefore, political stability could not be assured unconditionally by the Parliament, by introducing political censorship motions with certain and

${ }^{2}$ Article 99 CR: '(...) The presence of at least one minister is necessary in the Assembly debates. The assemblies can reject the presence of the ministers in their deliberations.' Our translation from Romanian: '(...) La desbaterile Adunărilor prezența a cel puțin un ministru e necesară. Adunările pot respinge prezența miniştrilor la deliberațiunile lor.’ 
direct effects. The monarch was a hindrance in this regard. The reciprocal was not valid. A Government that no longer enjoyed the support of the monarch had minimal chances to remain in office. It must be noted that in the dualist parliamentary regime, the leverage of the dissolution of the parliament wielded the risk to be exercised outside the parliamentary logic, so not for unblocking a governmental crisis. The right to dissolve the parliament as a whole or only one of the chambers offered the monarch the opportunity to impose his own political will. Interestingly, the People called for new elections did not rule on the conflict between the Parliament and the Government, but on the dispute between the Monarch and the Parliament 53 . The result of the expression of the People may not have suited the monarch's political actions. In such cases, it was important for the head of state to respect the will of the electorate ${ }^{54}$. The constitution did not prohibit cascade dissolution, but its spirit and general parliamentary practice prevented the monarch from abusing the dissolution power lever, in the idea of obtaining the desired parliamentary majority. Leaving his position of a political referee could generate endless institutional blockages.

As far as foreign policy is concerned, it was the monarch who represented the state, within the same limits of parliamentary rules. The expression of political visions in the field of international relations had to take place by committing the political responsibility of the prime minister or of the foreign ministers.

Taking into account the above underlined political formulas from within the Romanian Constitution of 1866 , we conclude that the monarch, in

53 Ibidem, 44.

54 M. Morabito, op. cit., p. 194. 
the logic of the dualist parliamentary regime, was not seated in the dictum 'the king reigns, but he does not govern', although there are some mechanisms that, taken in isolation, could (poorly) translate the opposite.

\section{Some landmarks from within the political and constitutional praxis of the period 1866-1914 - a 'denied' desired parliamentary regime}

In practice, the monarch, even without evading from the constitutional dictatorship (as already noted), could boast an active position in the scaffolding of powers in the state, especially if there was no political class possessing a coherent and adequate political thought, ideologically well connected or, in other words, a political class capable to assimilate, understand and implement the mechanisms of the parliamentary regime, especially the dualist one 55 . At the same time, for the smooth functioning of the dualist parliamentary regime, political ideologies had to be supported by consolidated political parties, few in number ${ }^{56}$, in order to easily obtain a stable majority after a hypothetical parliamentary dissolution 57.

In the first years of his reign, Carol I intended to be a moderating factor. After taking the oath:

\footnotetext{
55 M. GuȚAN, op. cit., p. 377.

${ }^{56}$ Ibidem, p. 378.

57 M. MORABITO, op. cit., p. 206.
} 
'I swear to guard the Constitution and the laws of the Romanian people, to maintain their national rights and the integrity of the territory.' 58

... he continued by pointing out that:

'The act that has been accomplished is the most important thing in the life of a People. Through the Constitution that we give today to the Romanian state, we achieve the legitimate aspirations of the nation, guaranteeing the interests of all, as well as all the rights that the citizen must find in a civilized society. This act is for me partly the most solemn of my life, for it is the definitive pact, which forever links me to the destinies of my new homeland, Romania. [...] The country enters a normal situation. A constitutional monarchical government is established. Let us all endeavor, however, that from the faithful and sincere application of the principles of this Constitution, it may produce its benefactors. ${ }^{5}{ }^{\prime}$

Carol I sincerely believed in the application of the Constitution adopted in 1866 . He believed in the constitutional regulation that brought the mechanisms of the parliamentary regime, hence the name of parliamentary constitutional monarchy. Becoming the first official of the state, the Lord was ready to strictly abide to the attributions recognized by the Constitution and its spirit, as required by article 35 .

$5^{8}$ Our translation from Romanian: 'Jur a păzi Constituțiunea și legile poporului român, a menține drepturile lui naționale şi integritatea teritoriului.' See Monitorul Oficial, nr. 142 of $1 / 13$ july 1866.

59 Out translation from Romanian: 'Actul ce s-a îndeplinit este cel mai însemnat din viața unui popor. Prin Constituțiunea ce dăm astăzi statului român realizăm aspirațiunile legitime ale națiunii, garantând interesele tuturor stărilor, precum și toate drepturile ce cetățeanul trebuie să găsească într-o societate civilizată. Acest act este pentru mine în parte este cel mai solemn al vieții mele, căci este pactul definitiv, care mă leagă pentru totdeauna cu destinele noii mele patrii, România. [...] Țara intră într-o stare normală. Un guvern monarhic constituțional este așezat. Să stăruim dar cu toții, ca din leala și sinceră aplicare a principiilor acestei Constituțiuni, ea să poată produce binefăcătoarele ei roade.' See ibidem. 
For example, regarding the exercise of the prerogative of appointing members of the Government, Carol's concern to appoint ministers from within the parliamentary majority became quite clear after the opening of the first session of the Assembly of Deputies on November 15/27, 1866, when the Government of I. Ghica was installed only after the support of the majority of moderate conservatives and liberals was obtained. The elections established a conservative majority. As a result, the Liberal I. Ghica submitted his resignation, which he withdrew only after obtaining the necessary parliamentary confidence for his cabinet. But this practice will be gradually forgotten, to the point where the Government will no longer be the emanation of parliament, e.g. D. Ghica's Cabinet of ministers (November 1868).

Similarly, in the beginning, the exercise of the prerogative of dissolving the Chambers was limited to the rules and spirit of the Constitution. For example, the dissolution of the legislative bodies of $1 / 13$ November 1867 , intervened as a result of the impossibility of forming a Government that would enjoy the support of the parliamentary majority. In time, the dissolution of the Chambers will also take on the character of a coup d'état, being used in the absence of conflicts between the Government and the Parliament or based on an observable change in the orientation of the electorate. Most dissolutions will have the purpose of enabling the Governments of certain parliamentary minorities to create, through new elections, the necessary parliamentary majority, e.g. the government of M. C. Epureanu, 1870. We will also encounter cases when the dissolution occurred due to external pressures, e.g. dissolution of the Chamber of Deputies in support of the government D. Ghica (1869) or L. Catargiu (1871) ${ }^{60}$.

60 T. DRĂGANU, op. cit., p. 278. 
Facing the numerous political factions immersed from the need to satisfy group interests (at one time, in two 'big' parties - the National Liberal Party and the Conservative Party), Carol I reacted by activating his monarchic personality. In concreto, he instrumented a political rotation between the political parties, using the parliamentary dissolution outside the box of its true political logic and outside the ratio of the principles of democracy (the elections were manipulated) ${ }^{61}$. Hence, in practice, the head of state reconfigured the parliamentary role and logic of the Government).

With the installation of the governmental rotation, the king used the constitutional leverage of parliamentary dissolution as a method of eliminating the unpopular majorities for certain Governments. At the end of the 19th century and the beginning of the 20th, the words of P. P. Carp: 'Your Majesty, give me the government and I give you the parliament and In Romania there are no parliamentary governments, but governmental parliaments, ${ }^{96}$ proved their content of truth. Under these conditions, the Government was a factor of imbalance, not of balance. It was the leverage of the dissolution of the Parliament and, therefore, only ensured an apparent form of political stability.

The parliamentary regime came to be absent in the king's political agenda. As a proof, in 1901, Carol I wrote to Maria de Flandra:

${ }^{61}$ R. C. Roghină, op. cit., ppp. 303-314; S. L. DAmEAn, Carol I al României 1866-1881, Vol. I, Edit. Paidea, Bucharest, 2000, ppp. 99-145; I. ScuRTu, Istoria românilor în timpul celor patru regi. Carol I, Editura Enciclopedică, Bucharest, 2011, ppp. 133-199.

62 Our translation from Romanian; 'Majestate, dați-mi guvernul și vă dau parlamentul și În România nu sunt guverne parlamentare, ci parlamente guvernamentale.'See P. CÂNCEA, M. Iosa, A. Stan (coord.), Istoria Parlamentului și a vieții parlamentare din România până la 1918, Academia Română (publishing house of the Romanian Academy), Bucharest, 1983, p. 166. 


\section{'The parliamentary system has become obsolete and should be removed if something else could be found for control.'63}

The governmental rotation of the political parties, which led to the finalization of the change of the poles of power between the Parliament and the Government, was for Carol I a system by which he managed to distort the ends of the constitutional mechanisms of the fundamental law. The king chose to alternate, depending on the political context, between the fall/maintenance of the Government and the dissolution of the Parliament.

The dualist parliamentary regime, built on the idea of the balance of powers in the state, existed only scripturally, in the Constitution. In practice, Carol I, aware of the moral power he possessed, and of the requirement for political stability that the Romanian state had to satisfy in the most credible way, sought to govern through the background/ realism of the Romanian society, that is, taking into account the true characters of the Romanian society (mainly those of the political class), and not through the (proven) utopian 'empty forms' contained in the fundamental law.

\section{Conclusion}

Based on the Constitution of 1866, the monarch was part of the national governing agenda. In time, the national governance agenda has been totally taken over by the monarch, given the reasons already stated. Gradually,

\footnotetext{
63 Our translation from Romanian: 'Sistemul parlamentar s-a perimat și ar trebui înlăturat dacă s-ar putea găsi altceva pentru control.' See S. CRISTEScu, Carol I și politica României (1878-1912), Paidea, Bucharest, 2007, p. 244.
} 
the Constitution was changed through practice, and an authoritarian regime with illusory parliamentary packaging was installed.

Carol I reigned and ruled. The Romanian monarch from 1866 was never put under the impossibility of governing, de jure and de facto. 